\title{
Shrub and dwarf shrub communities of Sangilen Plateau
}

\author{
Evgeny Zibzeev ${ }^{1, *}$, Natalia Igay ${ }^{l}$, Evgeny Sinkovskiy ${ }^{1}$, Sergey Savchuk ${ }^{2}$ and Vladimir \\ Lebed' $\mathrm{ko}^{2}$ \\ ${ }^{1}$ Central Siberian Botanical Garden of the Siberian Branch of the Russian Academy of Sciences, \\ 630090 Novosibirsk, Russia \\ ${ }^{2}$ V.F. Kuprevich Institute of Experimental Botany of National Academy of Sciences of Republic of \\ Belarus, 220072 Minsk, Belarus
}

\begin{abstract}
The paper presents a detailed ecological and caenotic characteristic of dwarf shrub and shrub communities growing in the highmountain belt of the Sangilen Plateau. The communities investigated were referred to the class of Loiseleurio-Vaccinietea Eggler 1952. The dwarf birch thickets with prevalence of Betula rotundifolia and the high incidence of Caragana jubata, Juniperus pseudosabina, J. sibirica, Pentaphylloides fruticosa, Salix glauca, Spiraea alpina were referred to the union of Carici tristis-Betulion rotundifoliae Zibzeev et al. 2018 of the order of Betuletalia rotundifoliae Mirkin at al. ex Chytrý Pešout et Anenkhonov 1993. Communities with dominant calciphilous shrubs and dwarf shrubs, such as Rhododendron adamsii, Caragana jubata, Salix berberifolia, S. reticulata, were referred to the union of Saxifrago oppositifoliae-Rhododendrion adamsii Zibzeev et al. 2018 of the order of Rhododendro-Vaccinietalia Br.-Bl. ex Daniels 1994.
\end{abstract}

\section{Introduction}

Shrub communities are the most common type of vegetation growing on the Sangilen Plateau. Prevalent are the communities formed by Betula rotundifolia, also common are communities with dominant Caragana jubata and Rhododendron adamsii.

Caragana jubata (Pall.) Poir. Is the Asian montane calciphilous shrub species, the habitat of which is related to the mountain systems of Central Asia, western Mongolia, China, Tibet, and the Himalayas. In the territory of Russia, the species covers the mountainous regions of Eastern Siberia and the Far East; the north-western boundary of its habitat goes along the Sangilen Plateau and certain ridges of south-eastern Altai (the Kurai and Chikhachev Ridges).

In the territory in question, Caragana jubata is found in the range of altitudes from $1900 \mathrm{~m}$ to 2550 meters. In deciduous forests consisting of Larix sibirica, it participates in the formation of the shrub tier. In river valleys and surrounded by cryophyte steppe, the species forms communities with co-dominance with Pentaphylloides fruticosa. In the

\footnotetext{
Corresponding author: egzibzeev@gmail.com
} 
mountain tundra belt, Caragana jubata forms vegetation communities with co-dominant Rhododendron adamsii and Betula rotundifolia.

Rhododendron adamsii Rehder is the north-Asian high-mountain calciphilous shrub species. In the territory of Russia, the western boundary of the habitat of Rhododendron adamsii goes along the Yenissei River, in the south, in western and eastern Tannu-Ola Range, the Sangilen Plateau, to go further to the mountain ridges of Eastern Sayan mountains, Khamar-Daban, Barguzin ridges, and in the north, it reaches the Aldan Highlands. In the Russian Far East, the habitat of Rhododendron adamsii stretches as far as the shore of the Sea of Okhotsk. Outside Russia, the species is commonly found in the mountain systems of Mongolia, and its southern boundary is in Tibet. In the territory of the Sangilen Plateau, Rhododendron adamsii grows in the high-mountain belt, where it forms communities on the carbonate rocky slopes of different exposure and steepness.

\section{Materials and Methods}

The study is based on 94 releves of high-mountain shrub communities performed by the authors in the upper reaches of the Naryn and Balyktyg-Hem Rivers in July 2014. The descriptions were made on the sample plots $100 \mathrm{~m}^{2}$ in area. The classification of the vegetation communities was made using the Braun-Blanquet method [1]. In this work, we used the concept of a differentiating species proposed by German geobotanists [2, 3]. The names of the syntaxa are provided in accordance with the International Code of Phytosociological Nomenclature [4].

\section{Results and discussion}

Cl. Loiseleurio-Vaccinietea Eggler 1952

Syntaxa prodromus

Ord. Betuletalia rotundifoliae Mirkin at al. ex Chytrý Pešout et Anenkhonov 1993

All. Carici tristis-Betulion rotundifoliae Zibzeev et al. 2018

Ass. Carici tristis-Betuletum rotundifoliae Zibzeev et al. 2018

Subass. Carici tristis-Betuletum rotundifoliae typicum Zibzeev et al. 2018

Subass. Carici tristis-Betuletum rotundifoliae caraganetosum jubatae Zibzeev et al. 2018 Ord. Rhododendro-Vaccinietalia Br.-B1. ex Daniels 1994

All. Saxifrago oppositifoliae-Rhododendrion adamsii Zibzeev et al. 2018

Resulting from the conducted classification of the shrub communities with dominant Betula rotundifolia, Ass. Saussureo schanginianae-Caraganetum jubatae Zibzeev et al. 2018

were referred to the union of Carici tristis-Betulion rotundifoliae, whereas the communities with Rhododendron adamsii and Caragana jubata were referred to the union of Saxifrago oppositifoliae-Rhododendrion adamsii of the order of Betuletalia rotundifoliae of the class of Loiseleurio-Vaccinietea.

The class of Loiseleurio-Vaccinietea unites alpine and arctoalpine dwarf shrub and shrub communities of Eurasia and North America. The communities of the Altai-Sayan mountain region and of Northern Mongolia were referred to the order of Betuletalia rotundifoliae.

In the southern part of the Altai-Sayan mountain region, situated in the rain shadow zone, grass-shrub communities are most common. Their geographic isolation, the physiognomic image and the high species saturation and specifics allowed us to refer them to a separate union of Carici tristis-Betulion rotundifoliae [5]. 
The union of Carici tristis-Betulion rotundifoliae unites grass-shrub communities of the semi-arid highlands of the of the Altai-Sayan mountain region and of northern Mongolia. Its diagnostic group is represented by high-mountain and arctic high-mountain species (Aconogonon alpinum, Betula rotundifolia, Carex tristis, Cetraria laevigata, Gentiana algida, Hedysarum consanguineum, Kobresia simpliciuscula, Pachypleurum alpinum, Ptilagrostis mongholica, Saussurea controversa, Swertia marginata, Vulpicidia tilesii). These communities are widespread in the altitude range of 2200-2500 m. They form their own sub-belt on the Sangilen Plateau.

Apart from Betula rotundifolia, Caragana jubata, Juniperus pseudosabina, J. sibirica, Pentaphylloides fruticosa, Salix glauca, and Spiraea alpina communities participate in the formation of the shrub tier. One of the peculiar features of the said communities is a large number of prostrate and hemi-prostrate dwarf shrubs. Besides Empetrum nigrum, Vaccinium uliginosum and V. vitis-idaea, widespread in all the communities of the class of Loiseleurio-Vaccinietea, Arctous erythrocarpa, Dryas oxyodonta, Salix berberifolia, $S$. reticulata, and $S$. turczaninowii are highly persistent and often abundant. Highly persistent in the communities under study are those species the habitat of which covers high-mountain regions of the mountains of southern Siberia, northern Mongolia, eastern Kazakhstan and the species sometimes found in the mountains of Central Asia: Callianthemum sajanense, Campanula turczaninovii, Claytonia joanneana, etc.

The association of Carici tristis-Betuletum rotundifoliae unites dwarf birch and shrub tundras of the Sangilen Plateau. These are dominant communities, widespread in the altitudinal range from 2200 to $2450 \mathrm{~m}$.

Diagnostic species: Aconogonon alpinum, Betula rotundifolia (dom.), Campanula turczaninovii, Cladonia coccifera, Cladonia uncialis, Gentiana algida, Peltigera aphthosa, Potentilla gelida, Sajanella monstrosa, Spiraea alpina.

The grass-dwarf-shrub tier is represented by one or two sub-tiers. The upper sub-tier (20-35 cm tall) is scarce, formed by Aconogonon alpinum, Hedysarum consanguineum, Gentiana algida, Ptilagrostis mongholica, Sajanella monstrosa, Trollius asiaticus, etc. The lower sub-tier (10-15 cm tall) is formed by Bistorta vivipara, Callianthemum sajanense, Campanula turczaninovii, Dracocephalum grandiflorum, Kobresia simpliciuscula, Pachypleurum alpinum, and Potentilla gelida.

In all the above communities, the moss-lichen tier is distinct (Cladonia arbuscula, $C$. coccifera, C. stellaris, Cetraria islandica, Flavocetraria cucullata, Hylocomium splendens, Polytrichum piliferum, Thamnolia vermicularis, Vulpicidia tilesii, etc.).

In the territory in question, the association is represented by two subassociations (C.t.B.r. typicum and C.t.-B.r. caraganoetosum jubatae). They differ by the character and degree of moisture content and the altitudinal and expositional characteristics.

The subassociation of C.t.-B.r. typicum unites moss-lichen-dwarf-birch tundras with domination of Betula rotundifolia in the shrub tier. These communities occupy relatively flat slopes $\left(1-7^{\circ}\right.$ steep), with well-expressed soil cover, in the altitudinal range of 2250 $2450 \mathrm{~m}$.

The shrub tier (40-50 cm tall) is formed by Betula rotundifolia. Besides the highly persistent round-leaved birch having insignificant projective coverage (1-3\%), Spiraea alpina and Salix glauca also occur. The grass-dwarf-shrub tier is represented by Aconogonon alpinum, Aster alpinus, Bistorta vivipara, Campanula turczaninovii, Festuca sphagnicola, Gentiana algida, Hedysarum consanguineum, Kobresia simpliciuscula, Potentilla gelida, Ptilagrostis mongholica, Sajanella monstrosa, Salix reticulate, Thalictrum alpinum, Trollius asiaticus, and Vaccinium vitis-idaea.

The moss-lichen tier occupies from 10 to $55 \%$ of the caenotic area. 
The subassociation of C.t.-B.r. caraganoetosum jubatae unites dwarf-birch tundras, formed on well-warmed slopes of southern exposure, $4-25^{\circ}$ steep. The altitudinal range of its habitat is $2000-2420 \mathrm{~m}$.

Diagnostic species: Callianthemum sajanense, Caragana jubata, Dracocephalum grandiflorum, Gentiana pseudoaquatica, Juniperus pseudosabina, Leontopodium ochroleucum, Pentaphylloides fruticosa.

Unlike a typical subassociation, the communities of the subassociation of C.t.-B.r. caraganoetosum jubatae are highly persistent, and Caragana jubata, Pentaphylloides fruticosa, Juniperus pseudosabina often have projective coverage. The grass-dwarf-shrub tier is scarce, except for the species characteristic for a typical subassociation: Callianthemum sajanense, Dracocephalum grandiflorum, Leontopodium ochroleucum, Potentilla nivea, Saussurea controversa, and Swertia marginata.

The union Saxifrago oppositifoliae-Rhododendrion adamsii contains calciphilous shrub communities with dominant Rhododendron adamsii, Caragana jubata and Salix berberifolia.

The obligate and facultative calciphilous species form the diagnostic group of the union: Androsace lehmanniana, Arctous erythrocarpa, Dactylina madreporiformis, Pachypleurum alpinum, Rhododendron adamsii, Salix berberifolia, S. reticulata, Saussurea schanginiana, Saxifraga oppositifolia.

The union is represented by two associations Saxifrago oppositifoliaeRhododendretum adamsii and Saussureo schanginianae-Caraganetum jubatae.

The association of Saxifrago oppositifoliae-Rhododendretum adamsii unites shrub communities, with dominant Rhododendron adamsii. In the territory in question, these communities are formed on steep slopes $15-25^{\circ}$ steep in the altitudinal range of 2400-2550 $\mathrm{m}$.

The diagnostic species are: Larix sibirica, Lloydia serotina, Oxytropis alpina, Rhododendron adamsii, Saxifraga oppositifolia.

The vertical structure consists of three tiers. The shrub tier is formed by Rhododendron adamsii, Betula rotundifolia, Salix glauca and Vaccinium uliginosum also occur. The grassshrub tier occupies up to $40 \%$ of the caenotic area. It is formed by Aster alpinus, Dryas oxyodonta, Gentiana algida, Hedysarum consanguineum, Kobresia myosuroides, Pachypleurum alpinum, Potentilla nivea, Saxifraga oppositifolia, Swertia marginate, et al. The moss-lichen tier occupies from 5 to $30 \%$ of the area, formed by Cetraria ericetorum, Cladonia arbuscula, Flavocetraria cucullata, Thamnolia vermicularis, Vulpicidia tilesii, Dicranum scoparium, Hylocomium splendens, Polytrichum commune, P. piliferum, and $P$. juniperinum.

The association of Saussureo schanginianae-Caraganetum jubatae unites shrub tundras with co-dominant Betula rotundifolia, Caragana jubata and Rhododendron adamsii

The diagnostic species: Arctous erythrocarpa, Caragana jubata, Lagotis integrifolia, Pedicularis tristis, Salix berberifolia, and Tephroseris heterophylla.

Unlike the above-described tundras, the associations of Saxifrago oppositifoliaeRhododendretum adamsii are commonly occurring communities of the lower third (2220$2400 \mathrm{~m}$ ) of the high-mountain belt of the Sangilen Plateau. They are found on the northern slopes $7-40^{\circ}$ steep.

The shrub tier (50-70 cm tall) is formed by Betula rotundifolia and Caragana jubata, with Juniperus pseudosabina, Pentaphylloides fruticosa and Salix glauca also present. In some above-described communities, Rhododendron adamsii and Vaccinium uliginosum form their own sub-tier (25-40 cm tall). The grass-dwarf-shrub tier is represented by Arctous erythrocarpa, Carex aterrima, Dryas oxyodonta, Empetrum nigrum, Hedysarum consanguineum, H. sangilense, Lagotis integrifolia, Pedicularis tristis, Ptilagrostis mongholica, Salix berberifolia. Saxifraga oppositifolia, Swertia marginata, and Trollius 
asiaticus. The moss-lichen tier occupies from 5 to $60 \%$. In the lichen synusia, Cetraria islandica, C. laevigata, Cladonia arbuscula and Flavocetraria cucullata dominate. In the moss synusia, Hylocomium splendens, Polytrichum piliferum, and $P$. juniperinum prevail.

\section{Conclusion}

The characteristic features of caenotic variability and spatial organization of the vegetation cover of the Sangilen Plateau are determined by the conditions of the semiarid climate and the characteristics of the geological and geomorphological structure of the area, edaphic factors, in particular, a high degree of soil mosaicism, related to outcrops of marmorized limestone and granite.

Resulting from the performed classification of the shrub and dwarf-shrub communities of the high-mountain belt of the Sangilen Plateau, three associations have been described. The shrub tundras of the class of Loiseleurio-Vaccinietea are the landscape-forming type of vegetation; in the lower part of the high-mountain belt, they form their own sub-belt, which occupies up to $2 / 3$ of the area of the highlands. 0004

Acknowledgement. The work was performed within the framework of state task No. 0312-2017-

\section{References}

1. V. Westhoff, E. van der Maarel, Handbook of vegetation sciences 5 (1973)

2. J. Dengler, C. Berg, F. Jansen, Annali di botanica, nuova serie 19 (2005)

3. T. Michl, J. Dengler, S. Huck, Phytocoenologia 40 (2-3) (2010)

4. H. E. Weber, J. Moravec, J.-P. Theurillat, J. Veg. Sci. 11(5) (2000)

5. E. G. Zibzeev, N. V. Igay, E. A. Basargin, Turczaninowia 21(1) (2018) 